Journal of Business and Management Studies (JBMS)

ISSN: $2709-0876$

DOI: $10.32996 / \mathrm{jbms}$

Journal Homepage: www.al-kindipublisher.com/index.php/jbms

\title{
Measuring the Influence of Product Placements in Korean Dramas on the Act of Purchase of Filipino Audiences
}

\author{
Bernard Angelo C. Advincula ${ }^{1} \square$ Madelaine D. Bernardo ${ }^{2}$ and Andrea Nicole C. Soriano ${ }^{3}$ \\ ${ }^{123}$ College of Commerce and Business Administration; University of Santo Tomas; Manila, Philippines \\ $\square$ Corresponding Author: Bernard Angelo C. Advincula, E-mail: bernardangelo.advincula.comm@ust.edu.ph
}

\begin{tabular}{|c|c|}
\hline ARTICLE INFORMATION & ABSTRACT \\
\hline Received: 15 October 2021 & \multirow{6}{*}{$\begin{array}{l}\text { Nowadays, product placements are becoming a prominent marketing strategy used } \\
\text { primarily on films in other countries, such as in Korean dramas, but rarely or poorly } \\
\text { done in the Philippines. This research aims to determine if the perceived influence of } \\
\text { actors, product-story congruence, and the perceived influence of product function } \\
\text { affects the Filipino audiences' act of purchase. The study consisted of } 200 \text { male and } \\
\text { female audiences of Korean dramas, ages } 18 \text { to } 34 \text { years old and used simple random } \\
\text { sampling. The validity and reliability of the survey were also tested, consisting of } 30 \\
\text { respondents with an alpha value of } 0.936 \text {. Regression analysis was utilized to analyze } \\
\text { the strength of correlations between the independent and dependent variables. The } \\
\text { results show that all of the three independent variables are significant to the dependent } \\
\text { variable, which implies that it affects their act of purchase and brand awareness. }\end{array}$} \\
\hline Accepted: 12 November 2021 & \\
\hline Published: 31 December 2021 & \\
\hline DOI: 10.32996/jbms.2021.3.2.28 & \\
\hline KEYWORDS & \\
\hline $\begin{array}{l}\text { Media, Entertainment, Korean } \\
\text { drama, Product Placement, } \\
\text { Consumer Behavior, Marketing, } \\
\text { Advertising }\end{array}$ & \\
\hline
\end{tabular}

\section{Introduction}

While product placement is an excellent tool for advertising products, some audiences prefer a subtle execution method rather than an obvious one as they find it bothersome. Product placement may also demonstrate the value of the product shown because it is incorporated into the Korean drama's plot. The popularity of the actors and how they can provide a positive image to the brand being endorsed are two of the most important elements that influence viewers' desire to buy. Moreover, the perceived influence of product function impacts the effectiveness of product placement on brand positioning (Perwitasari et al., 2020). The product-story congruence pertains to the integration of the placed product to the storyline or plot of the drama (Cheon et al., 2016). Filipinos are one of the audiences who are easily influenced by Korean drama product placements, especially when it comes to food and beauty products. Subway, Laneige, Jin Soju, Shin Ramyun, and Samsung are some of the very familiar brands to the Filipino audiences. While these products are well-known in South Korea, the actors who are endorsing them also play a significant role in Filipino audiences' purchasing behaviour. The level of influence of the actors does not only depend on how famous they are but also on the role they are portraying and the storyline of the film or movie. In the Philippines, product placements are either rare or poorly done. They are usually done in Filipino movies and teleseryes like Kita Kita (Sapporo Beer), She's Dating the Gangster (KFC \& iWANTV), Four Sisters, and a Wedding (Rebisco biscuits), Ang Probinsyano (Nescafe coffee), and many more. Some Filipino audiences find the execution of product placements done by the local industry banal. There was minimal research conducted to study the effects of product placement in the Philippines. Therefore, of particular interest in this study is the influence of product placements in Korean dramas and how it is different from the product placement done in the Philippine media industry from the perspective of Filipino consumers.

\section{Methodology}

In order to understand the impact of product placements on the purchasing behaviour of Filipino audiences, the researchers used a quantitative method. The researchers' aim is to have an in-depth understanding of the factors that affect their act of purchase, such as the perceived influence of actors, product-story congruence, and the perceived influence of product function of the Filipino audiences. A pilot study was undertaken to assess the validity and reliability of the survey instrument by inviting 30 respondents to participate in the survey. Their responses were used for the validity and reliability assessment of the concept as raw data. After

Copyright: (C) 2021 the Author(s). This article is an open access article distributed under the terms and conditions of the Creative Commons Attribution (CC-BY) 4.0 license (https://creativecommons.org/licenses/by/4.0/). Published by Al-Kindi Centre for Research and Development, London, United Kingdom. 
pilot testing the questionnaire, the researchers conducted an online survey with 200 Korean drama audiences. In addition, a descriptive cross-sectional design was employed to gather data from participants at a specific moment in time. A simple random sampling technique was utilized to gather data efficiently and effectively with the number of samples of 200 respondents based on the prior statistical power analysis using $\mathrm{G}$ Power with power $=.95(1-\beta)$, effect size $=.10$, and $\alpha=.05$. After a week of data collection, the researchers used frequency and percentage distributions as well as weighted mean to interpret the Likert-type questions. Multiple regression analysis was employed to examine the correlations between independent and dependent variables to anticipate the precise outcome. The purpose of the test is to determine if the product placement in Korean dramas influences the act of purchase of Filipino audiences.

The viewers' attitudes towards the brand were strongly influenced by the characters. H1: Consumer attitude toward the TV drama will positively influence attitude toward the placed brand. H2: Product-story congruence will positively influence (a) attitude toward the TV drama and (b) attitude toward the placed brand. H3: The perceived similarity will positively influence (a) attitude toward the TV drama and (b) attitude toward the placed brand. H4: The perceived likability will positively influence (a) attitude toward the TV drama and (b) attitude toward the placed brand (Cheon et al., 2016). The Hypothesized Model is presented in Fig. 1.

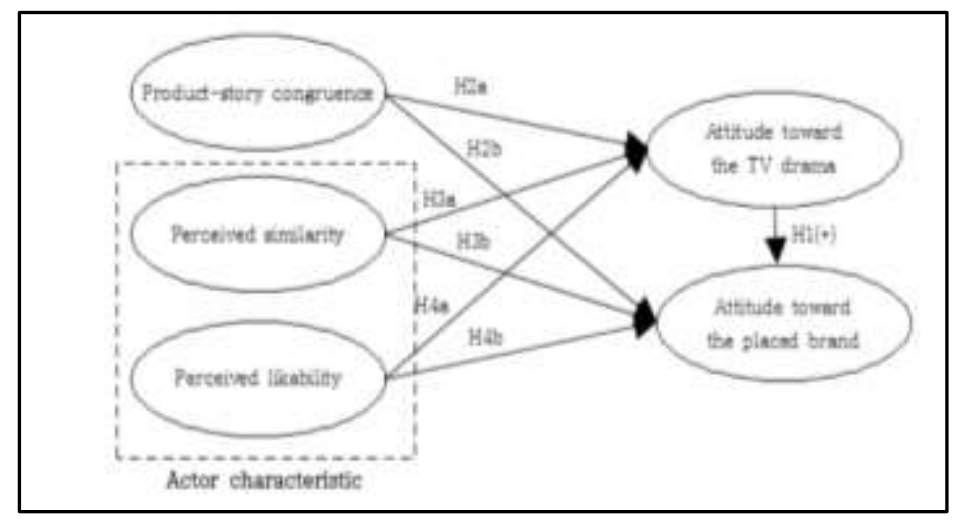

\section{Figure 1: Hypothesized Model}

The quality of a product being shown in the product placement helps increase customers' willingness to buy the products because the buyer expects excellent results when buying a product. Another important thing to do in product placement to increase customers' willingness to buy products is to perform screen tests to ensure the product's appearance looks natural and creates curiosity from viewers or customers' eyes (Perwitasari, 2020). The models are shown in Figures 2 and 3 explain each variable's relation to the effectiveness of product placement for brand positioning and how product placement encourages customers' willingness to buy products.
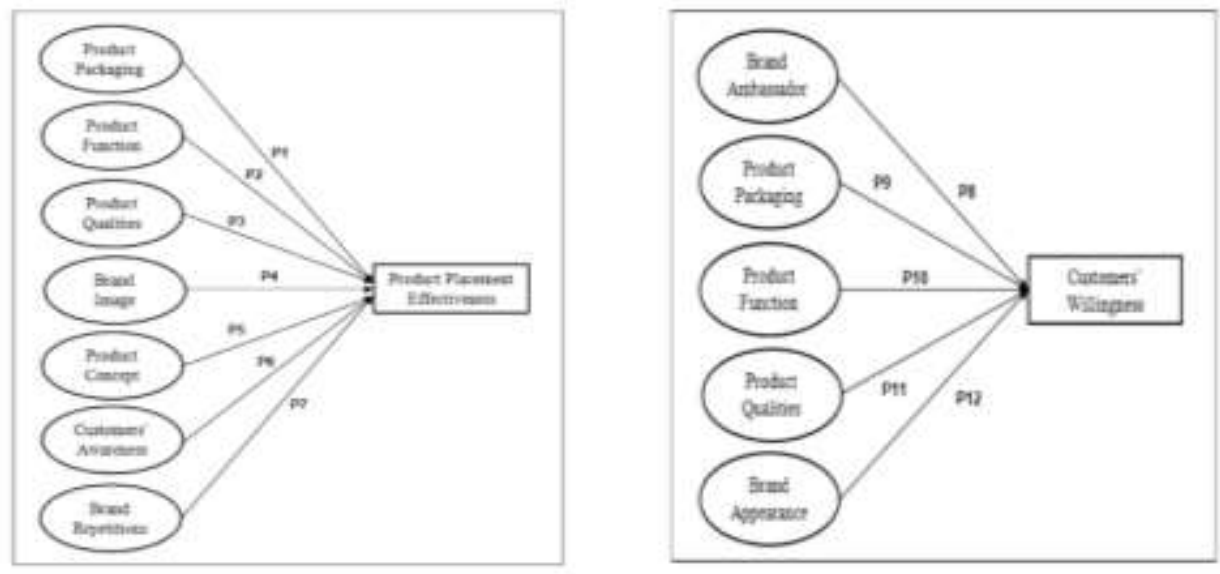

Figure 2: Factors that make Product Placement an Effective Tool for Brand Positioning Figure 3: Factors that make Product Placement Increase Customers' Willingness to Buy Products 
The figures shown below are the dependent and independent variables in the study, which contains what the researchers expect to find out through the research. The act of purchase of Filipino audiences serves as the dependent variable, while the perceived influence of actor, product-story congruence, and the perceived influence of product function are the independent variables. The study will measure how the independent variables influence the act of purchase of Filipino audiences through product placement.

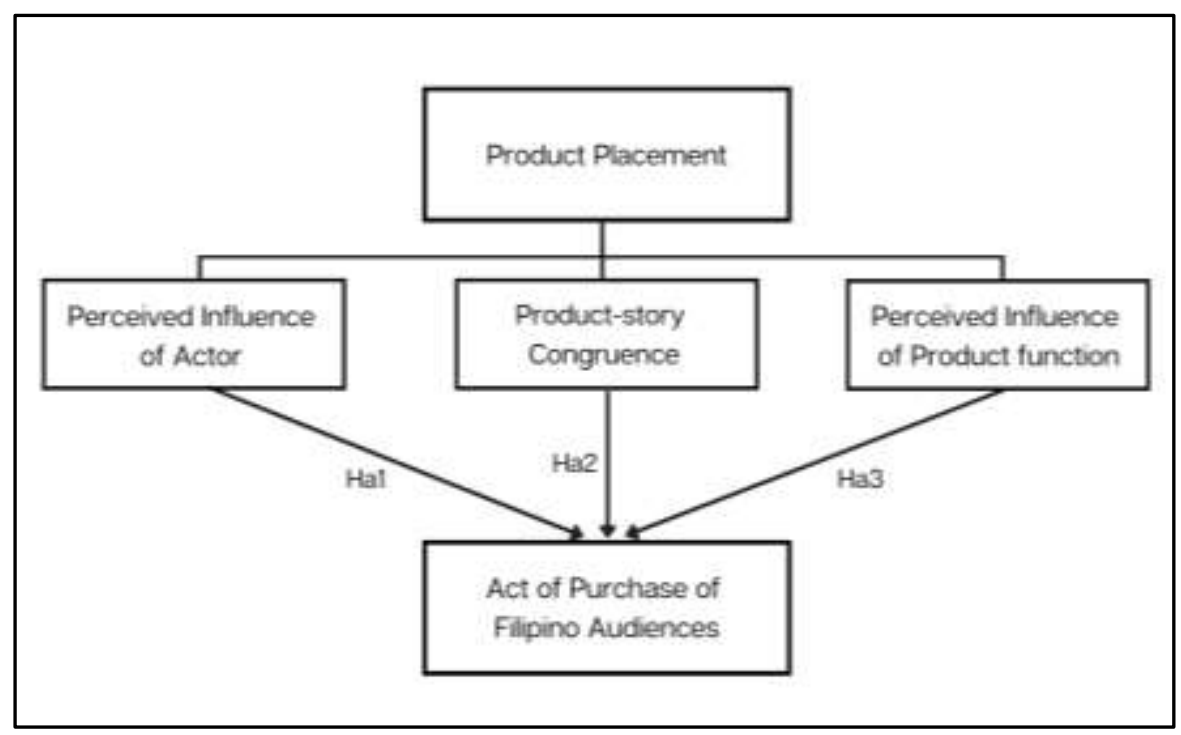

Figure 4: Factors affecting the act of purchase of Filipino audiences

This study aims to measure the influence of product placement in Korean dramas to know its effectiveness towards Filipino audiences. The research also aims to know if such a strategy would benefit Filipino local brands and the Philippine entertainment industry. In consideration of this, this research will seek to answer the following questions:

RQ1: What are the general characteristics of the respondents' demographics?

RQ2: How can the perceived influence of actors in Korean dramas affect the act of purchase of Filipino audiences?

RQ3: How can the product-story congruence affect the act of purchase of Filipino audiences?

RQ4: How can the perceived influence of product function affect the act of purchase of Filipino audiences?

\section{Results and Discussion}

As shown in Table 3.1, out of 200 respondents, fifty-eight (58) or $28.60 \%$ are $18-21$ years old, while thirty-nine (39) or $19.20 \%$ are 30-34 years old. When it comes to gender, most of the respondents who answered the survey are female respondents, with $76.80 \%$. When it comes to their location, it shows that eighty-three (83) or $40.90 \%$ of the respondents are from the National Capital Region, forty-eight (48) or $23.60 \%$ of the respondents are from Luzon, forty-two (42) or $20.70 \%$ of the respondents are from Visayas, and lastly, thirty (30) or $14.80 \%$ are from Mindanao. 
Table 1: Demographic Profile of the Respondents $(n=200)$

\begin{tabular}{|c|c|c|c|}
\hline Demographic & Criteria & Frequency & $\%$ of Total \\
\hline \multirow[t]{4}{*}{ Age } & $18-21$ & 58 & $28.60 \%$ \\
\hline & $22-25$ & 56 & $27.60 \%$ \\
\hline & $26-29$ & 50 & $24.60 \%$ \\
\hline & $30-34$ & 39 & $19.20 \%$ \\
\hline \multirow[t]{2}{*}{ Gender } & Male & 47 & $23.20 \%$ \\
\hline & Female & 156 & $76.80 \%$ \\
\hline \multirow[t]{4}{*}{ Location } & NCR & 83 & $40.90 \%$ \\
\hline & Luzon & 48 & $23.60 \%$ \\
\hline & Visayas & 42 & $20.70 \%$ \\
\hline & Mindanao & 30 & $14.80 \%$ \\
\hline
\end{tabular}

Table 2: Perceived Influence of Actors, Product-Story Congruence, Perceived Influence of Product Function

\begin{tabular}{llll}
\hline Indicator & Mean & S.D. & Verbal Interpretation \\
\hline $\begin{array}{l}\text { I observe how the product/s are being used in the } \\
\text { Korean drama }\end{array}$ & 3.42 & 0.736 & Influential \\
$\begin{array}{l}\text { I am more interested in buying if the product features } \\
\text { are highlighted by the actors instead of its brand }\end{array}$ & 2.90 & 0.917 & Influential \\
$\begin{array}{l}\text { I get interested with the placed product/s if the actor } \\
\text { interacts with it }\end{array}$ & 3.22 & 0.865 & Influential \\
$\begin{array}{l}\text { The actors give a positive image to the placed } \\
\text { product/s in Korean drama }\end{array}$ & 3.48 & 0.647 & Influential \\
$\begin{array}{l}\text { I can say that product placement in Korean dramas are } \\
\text { executed well }\end{array}$ & 3.50 & 0.706 & Influential \\
\hline \begin{tabular}{l} 
Perceived Influence of Actors \\
\hline
\end{tabular}
\end{tabular}




\begin{tabular}{|c|c|c|c|}
\hline $\begin{array}{l}\text { I buy the product/s if my favourite actor is connected } \\
\text { with it and with the plot of the story }\end{array}$ & 2.68 & 0.970 & Influential \\
\hline $\begin{array}{l}\text { I remember the brand of the placed product/s } \\
\text { depending on how many times it was shown in the } \\
\text { Korean drama }\end{array}$ & 3.28 & 0.793 & Influential \\
\hline I purchase a product after seeing it in the Korean drama & 2.25 & 0.960 & Less Influential \\
\hline Product-Story Congruence & 2.74 & 0.678 & Influential \\
\hline $\begin{array}{l}\text { I do not find product placements in Korean dramas } \\
\text { irritating or bothersome }\end{array}$ & 3.36 & 0.728 & Influential \\
\hline $\begin{array}{l}\text { The presence of product placements in Korean drama } \\
\text { makes the scenes more realistic }\end{array}$ & 3.05 & 0.918 & Influential \\
\hline $\begin{array}{l}\text { I consider buying the placed product/s in the Korean } \\
\text { drama if I saw that they are effective or useful }\end{array}$ & 3.20 & 0.779 & Influential \\
\hline I trust the brand of the product/s used in Korean dramas & 3.09 & 0.715 & Influential \\
\hline Perceived Influence of Product Function & 3.18 & 0.565 & Influential \\
\hline $\begin{array}{l}\text { I will consider the brand that I saw in Korean drama the } \\
\text { next time I will purchase a product }\end{array}$ & 3.10 & 0.724 & Influential \\
\hline $\begin{array}{l}\text { I tend to buy the product/s in Korean drama out of } \\
\text { curiosity }\end{array}$ & 2.70 & 0.991 & Influential \\
\hline $\begin{array}{l}\text { I buy the exact same brand that I saw from the Korean } \\
\text { drama }\end{array}$ & 2.66 & 0.979 & Influential \\
\hline Act of Purchase & 2.82 & 0.756 & Influential \\
\hline
\end{tabular}

Table 2 illustrates the 3 variables on Measuring The Influence of Product Placements in Korean Dramas on the Act of Purchase of Filipino Audiences. Overall, the Perceived Influence of Actors is interpreted as Influential, with a general mean of 3.30 and a standard deviation of 0.548 . The perceived influence of actors triggers the audiences' curiosity when it comes to the product/s that they are using. It was also discovered that the actors in Korean dramas give a positive image to the product that they are using, which affects the purchase intention of the audiences. Moreover, Product-Story Congruence is interpreted as Influential, with a general mean of 2.74 and a standard deviation of 0.678 , while one indicator is Less Influential with a mean of 2.25 and a standard deviation of 0.960 . This means that the subtle way of execution and the value of the product to the plot contributes to the purchase decision of the audiences instead of just showing it and not connecting the product in a particular scene or act on the Korean drama. The Perceived Influence of Product Function is interpreted as Influential, with a general mean of 3.18 and a standard deviation of 0.565 . It has been found that the purchase intention of the Filipino audiences increases when the usefulness of the placed product/s are being shown in the drama. The Act of Purchase is interpreted as Influential, with a general mean of 2.82 and a standard deviation of 0.756 . This implies that product placements are sufficiently effective to impact audiences' purchasing 
behaviour and decisions since they are easily persuaded by the products shown in Korean dramas and consider and buy the exact same brand that they saw from the Korean drama they watched.

Table 3: Regression Results of the 3 variables on the Influence of product placements in Korean dramas on the act of purchase of Filipino audiences

\begin{tabular}{|c|c|c|c|c|c|}
\hline Predictor & Estimate & SE & $\mathbf{t}$ & $\mathbf{p}$ & Interpretation \\
\hline Intercept & -0.0799 & 0.2519 & -0.317 & 0.751 & \\
\hline \multicolumn{6}{|l|}{ Perceived } \\
\hline $\begin{array}{c}\text { Influence of } \\
\text { Actors }\end{array}$ & 0.578 & 0.0838 & 5.234 & $<.001$ & Ha1 Accepted \\
\hline $\begin{array}{c}\text { Product Story } \\
\text { Congruence }\end{array}$ & 0.5963 & 0.065 & 9.168 & $<.001$ & Ha2 Accepted \\
\hline \multicolumn{6}{|l|}{ Perceived } \\
\hline $\begin{array}{c}\text { Influence of } \\
\text { Product }\end{array}$ & 0.3672 & 0.0812 & 4.521 & $<.001$ & Ha3 Accepted \\
\hline Function & & & & & \\
\hline
\end{tabular}

Regression Analysis was calculated by examining the variables - Perceived Influence of Actors, product story congruence, and product function. It implies that there is evidence to accept the alternative hypothesis (Ha1) that the perceived influence of actors has a significant effect on the act of purchase of Filipino audiences. Additionally, the alternative hypothesis (Ha2) is accepted, which states that the product-story congruence influences the act of purchase of Filipino audiences. With the perceived influence of product function, the alternative hypothesis ( $\mathrm{Ha} 3$ ) is accepted, which states that it significantly influences the act of purchase of Filipino audiences. It proved that all three variables significantly affect the act of purchase of Filipino audiences, as illustrated in Table 3, having the same p-value of 0.001 . This is an indication that product placements in Korean dramas are sufficiently effective to persuade Filipino audiences to purchase the featured product/s.

\section{Conclusion and Recommendations}

The stated implications will greatly affect the Philippine entertainment industry if they adopt the techniques and strategies for product placement in Korean Dramas, as this will significantly impact Filipino consumers' act of purchase. Additionally, interviewees claimed that it would be effective as long as it is incorporated into the story in a distinctive way to attract and reach potential customers. Furthermore, interviewees agreed that utilizing product placements may be costly, but it is a great investment for brands because it is less cluttered than traditional TV ads and unskippable online ads. The results have shown that all three independent variables are significant to the dependent variable. It was found that the Perceived Influence of Actors, Product-story Congruence, and Perceived Influence of Product Function greatly influences the act of purchase of Filipino audiences.

As a result, the Perceived Influence of Actors is evaluated as significant, implying that actors play a significant role in the execution of product placement. The actors' projection also adds to the successful delivery of the brand's hidden messages, and when the actors highlight and accentuate the products' usefulness, the audience's intention to purchase increases. Also, it has been determined that the audiences will purchase the advertised placed product/s if they are closely related to the plot of the Korean drama. This indicates Product-story Congruence and the subtle execution and the significance of the product to the plot contribute to the act of purchase of the Filipino audiences, rather than simply showcasing it and without relating it to a specific moment or scene in the Korean drama. Additionally, the actors should be valued similarly to the product being featured, as this is a good opportunity for the brand to thrive based on the show's content. Moreover, the Perceived Influence of Product Function significantly affects the customer's willingness to purchase, proving that it substantially impacts the Filipino audience's act of purchase.

The product placements in Korean dramas were examined in this study to identify their influence on the act of purchase of Filipino audiences. In light of the conclusion of findings, the study, therefore, proceeds to recommend the following: To the advertisers and marketing managers as the Filipino audiences are found to be influenced by famous personalities with regard to their purchasing decision. They must take time to thoroughly review the show's storyline and values to make sure that the products endorsed are accurately aligned with them. It is also important for them to mainly highlight the function of a product rather than showing it for mere displays as it would look more realistic and relatable to the audiences, making the product placement more effective and useful. The researchers also suggest it to the Brands and Media Industry too. Different businesses in the Philippines, especially the Micro, Small and Medium Enterprises, could consider investing in product placements as this aids the Filipino 
audiences when it comes to brand awareness. Furthermore, the researchers also recommend the media industry to further study how to execute product placements in a subtle manner as it is found to be effective in capturing the attention of the Filipino audiences and their purchasing intentions.

Funding: This research received no external funding and was only conducted in a span of 6 months. The researchers recommend further validation of this study through additional data gathering, a more thorough statistical analysis, and other variable relationships.

Acknowledgements: The success of this research study would never be possible without the support and guidance of various people who were with the researchers throughout the entire duration of the study. The researchers are extending their gratefulness and appreciation to Dr. Caroline Castano, PhD, Ms. Marie Abigail Posadas, MBA, Mrs. Madel Magsino-Marasigan, MBA, Mr. Emman Paulino, DBA, LPT, Dr. Francis Lawrence De Jesus, Ph.D., Dr. Agnes Jocelyn Bandojo, DBA, Mr. Real So, MBA, MA ENG., MA LIT, Dr. Antonio Etrata Jr., Ph, D., Ms. Jamie Bautista, Mr. James Dala, Ms. Lica Arroyo, the family and friends of the researchers, and lastly, to the Almighty God.

Conflicts of Interest: The authors declare no conflict of interest.

\section{References}

[1] Alexander, J. (2018). Verbal and Non-verbal communication in product placement "Descendants of the Sun." Kata Kita, 5(2), 72-76. https://doi.org/10.9744/katakita.5.2.72-76

[2] Barker, C. (2016). Research Methods in Clinical Psychology: An Introduction for Students and Practitioners (3rd ed.). Oxford, UK: John Wiley \& Sons, Ltd. https://doi.org/10.4236/psych.2018.98126

[3] Barroso, N. (2011). The effects of product placement, in films, on the consumer's purchase intentions. ISCTE Business School. https://repositorio.iscte-iul.pt/bitstream/10071/4724/1/Tese_Nuno_Barroso.pdf

[4] Bae, A. (2021). Top Korean Drama Streaming Sites And Their Ongoing Dramas. Kdramapal. https://www.kdramapal.com/top-korean-dramastreaming-sites-ongoing-dramas/

[5] Bi, N. C., \& Zhang, R.(2019). Do K-Pop consumption and direct contact with Koreans affect American audiences' perception of South Korea and its products?. Asian Communication Research, 16(1), 72-104. https://doi.org/10.20879/acr.2019.16.1.72

[6] Cabral, J. (2018). Is Generation Y Addicted to Social Media?. Strategic Communications Elon University. https://www.elon.edu/u/academics/communications/journal/wp-content/uploads/sites/153/2017/06/EJSpring11_Full.pdf

[7] Cenidoza, M., \& Igno, J. (2016). Beyond the "Fad": Understanding Hallyu in the Philippines. International Journal of Social Science and Humanity, 6(9), 723-727. https://doi.org/10.7763/ijssh.2016.v6.740

[8] Cohen, J. (1988). Statistical Power Analysis for the Behavioral Sciences. https://doi.org/10.4324/9780203771587

[9] Cohen, J. (1990). Things I Have Learned (so far). American Psychologist, 45, 1304-1312. https://doi.org/10.1037/0003-066X.45.12.1304

[10] Cohen, J. (1992). A Power Primer. Psychological Bulletin, 112, 155-159. https://doi.org/10.1037/0033-2909.112.1.155

[11] Cha, J. (2016). Product placement in movies: Perspectives from motion picture firms. Journal of Media Business Studies, 13(2), 95-116. https://doi.org/10.1080/16522354.2016.1159802

[12] Cheah, I. (2018). Idolizing "My Love from the Star": Idol attachment and fanaticism of luxury brands. Psychology \& Marketing, 36(2), $120-137$. https://doi.org/10.1002/mar.21163

[13] Cheon, M. (2016). Product-story congruence and actor attractiveness in product placements in television drama. Journal of Fashion Business, 20(3), 104-118. https://doi.org/10.12940/jfb.2016.20.3.104

[14] Cui, M., \& Lee, S. S. (2015). Chinese consumers' purchase intention of the goods inside Korean TV dramas product placement. Family and Environment Research, 53(4), 341-350. https://doi.org/10.6115/fer.2015.027

[15] Davtyan, D., \& Cunningham, I. (2017). An investigation of brand placement effects on brand attitudes and purchase intentions: Brand placements versus TV commercials. Journal of Business Research, 70, 160-167. https://doi.org/10.1016/j.jbusres.2016.08.023

[16] Dworkin, S.L. (2012). Sample size policy for qualitative studies using in-depth interviews. Archives of Sex Behavior, 41, 1319-1320. https://doi.org/10.1007/s10508-012-0016-6

[17] Fong Y. C, F., \& Lowe, B. (2017). Product placement practices in prime-time television programmes in Hong Kong. International Journal of Advertising, 37(6), 984-1009. https://doi.org/10.1080/02650487.2017.1353263

[18] Grundmeyer, T.A. (2012). A qualitative study of the perceptions of first-year college students regarding technology and college readiness. Graduate Theses and Dissertations. 12599. https://lib.dr.iastate.edu/etd/12599/

[19] Guo, F. (2019). Product Placement in Mass Media: A Review and Bibliometric Analysis. Journal of Advertising, 48(2), $215-231$. https://doi.org/10.1080/00913367.2019.1567409

[20] Halim, T. M., \& Kiatkawsin, K. (2020). The Influence of Korean Entertainment in K-Beauty Products and Visit Intention: A Study of Indonesian Female Consumers. Korea Tourism Association International Conference Collection. http://www.papersearch.net/thesis/article.asp?key=3841659.

[21] Jianyi, D. (2017). A study of product placement and audience's brand image construction. Journal of the Korean Entertainment Industry Society, 11(8), 41-48. https://doi.org/10.21184/jkeia.2017.12.11.8.41

[22] Jung, E., \& Childs, M. (2019). Destination as product placement: An advertising strategy to impact beliefs and behavioural intentions. Journal of International Consumer Marketing, 32(3), 178-193.https://doi.org/10.1080/08961530.2019.1662355

[23] Juwita, S. I. M. (2017). Samsung Galaxy Note Edge Mobile product placement in Pinocchio Korean drama to increase Galaxy Note brand awareness. Communication Management Proceedings, 3(2), http://karyailmiah.unisba.ac.id/index.php/mankom/article/view/8712

[24] Kim, N., \& Hong, L. (2017). The power of culture in branding: How the Korean wave can help global brands thrive in Asia. Journal of Brand Strategy, https://www.ingentaconnect.com/content/hsp/jbs/2017/00000006/00000003/art00010 
[25] Kishiya, K. (2018). Exploring the impact of celebrity endorsement on product placement effectiveness. International Journal of Marketing \& Distribution, 2(1), 25-35. https://doi.org/10.5844/ijmd.2.1_25

[26] Kock, N. (2015). Common Method Bias in PLS-SEM: A Full Collinearity Assessment Approach. International Journal of e-Collaboration (IJeC), 11(4), 1-10. http://doi.org/10.4018/ijec.2015100101

[27] Kumar, S. (2017). Influence of product placements in films and television on consumers Brand Awareness. Archives of Business Research, 5(2). https://doi.org/10.14738/abr.52.2747

[28] Knoll, J., \& Matthes, J. (2017). The effectiveness of celebrity endorsements: a meta-analysis. J. of the Acad. Mark. Sci. 45, 55-75. https://doi.org/10.1007/s11747-016-0503-8

[29] Kyriazos, T. (2018) Applied Psychometrics: Sample Size and Sample Power Considerations in Factor Analysis (EFA, CFA) and SEM in general. Psychology, 9(8), 2207-2230. http://doi.org/10.4236/psych.2018.98126

[30] Laban, G. (2020). Binge-watching (Netflix) product placement: A content analysis on different product placements in Netflix originals vs nonNetflix originals and drama vs comedy shows. https://doi.org/10.33767/osf.io/hxjgf

[31] Langun, J. (2015). The influence of the perception of PPL in Korean dramas on the brand image and purchase intention of Korean and Chinese consumers-focusing on restaurants-. The Korean Culinary Society, 21(4), 309-324. https://doi.org/10.20878/cshr.2015.21.4.022

[32] Lavrakas, P. (2011). Encyclopedia of Survey Research Methods. Sage Research Methods. http://dx.doi.org/10.4135/9781412963947.n195

[33] Lee, H. E. (2018). An empirical analysis of the role of social media in Korean media and product consumption. International Journal of Advanced Culture Technology, 6(4), 179-189. https://doi.org/10.17703//IJACT2018.6.4.179

[34] Lee, T. (2011). "Cross-cultural challenges in product placement", Marketing Intelligence \& Planning, 29( 4), 366-384. https://doi.org/10.1108/02634501111138545

[35] Liang, A. (2015). The Effects of Product Placement and Television Drama Types on the Consumer Responses of College Students, Asia Pacific Journal of Tourism Research, 20(11), 1212-1233. https://doi.org/10.1080/10941665.2014.969285

[36] Meyer, J. (2016). The effect of product placements on the evaluation of movies. European Journal of Marketing, 50(3/4), 530-549. https://doi.org/10.1108/EJM-12-2014-0758

[37] Nagar, K. (2016). Consumer response to brand placement in movies: Investigating the brand-event fit. Vikalpa: The Journal for Decision Makers, 41(2), 149-167. https://doi.org/10.1177/0256090916642678

[38] Parengkuan V. J., Tulung, J. E., \& Arie, F. V. (2020). Influence of product placement in movies and television programs towards brand recall of millennials. Journal of Economic Research, Management, Business and Accounting, 8(1). https://doi.org/10.35794/emba.v8i1.28060

[39] Park, Y.-S. (2015). Does the rise of the korean wave lead to cosmetics export? The Journal of Asian Finance, Economics and Business, 2(4), 1320. https://doi.org/10.13106/jafeb.2015.vol2.no4.13.

[40] Perwitasari, D. A., \& Paramita, E. L. (2020). Product placement on Korean drama as an effective tool for brand positioning (Case study: Laneige). Jurnal Muara Ilmu Ekonomi Dan Bisnis, 4(1), 145. https://doi.org/10.24912/jmieb.v4i1.7717

[41] Posadas, A. J. (2021). Perceived influence of Korean drama in the culture of student viewers in Central Luzon State University. https://doi.org/10.2139/ssrn.3768149

[42] Philippine Statistics Authority. (n.d). 2010 Census-based Population Projections in collaboration with the Inter-Agency Working Group on Population Projections. https://psa.gov.ph/sites/default/files/attachments/hsd/pressrelease/Table4_9.pdf

[43] Reneicke, L., \& Oliver, M. B. (2017). The Routledge Handbook of Media Use and Well-Being. Google Books. https://books.google.com.ph/books?hl=en.

[44] Richland, L. E. (2009). The pretesting effect: Do unsuccessful retrieval attempts enhance learning. Journal of Experimental Psychology: Applied, 15(3), 243-257. https://doi.org/10.1037/a0016496

[45] Russell, C. A., \& Rasolofoarison, D. (2017). Uncovering the power of natural endorsements: a comparison with celebrity-endorsed advertising and product placements. International Journal of Advertising, 36(5), 761-778. https://doi.org/10.1080/02650487.2017.1348033

[46] Sanap, J. (2017). Pros and cons of different sampling techniques. International Journal of Applied Research. 3(7), 749-752. https://www.academia.edu/38683557/Impact_Factor_5_2_IJAR?bulkDownload=thisPaper-topRelated-sameAuthor-citingThis-citedByThissecondOrderCitations\&from=cover_page.

[47] Sarstedt, M. (2014). Regression Analysis. A Concise Guide to Market Research, 193-233. https://link.springer.com/chapter/10.1007\%2F978-3642-53965-7_7.

[48] Seo, J. H., \& Kim, B. (2019). The "Hallyu" phenomenon: Utilizing tourism destinations as product placement in K-POP culture. Tourism Economics, 26(4), 719-728. https://doi.org/10.1177/1354816619837111

[49] Siddharth, K. (2021). Statistical treatment of data. Explorable.com. https://explorable.com/statistical-treatment-of-data

[50] Shorten, A., \& Smith, J. (2017). Mixed methods research: Expanding the evidence base. BJM Journals. 20(3) http://dx.doi.org/10.1136/eb2017-102699

[51] Srivastava, R. K. (2016). Promoting brands through product placement in successful and unsuccessful films in emerging markets. Journal of Promotion Management, 22(3), 281-300. https://doi.org/10.1080/10496491.2015.1095831

[52] Teh, P. Y., \& Goh, H. C. (2016). Does Korean drama have a real influence? An analysis of Malaysia outbound tourists to South Korea. Tourism Culture \& Communication, 16(3), 147-160.https://doi.org/10.3727/109830416X14750895902882

[53] Utomo, N. K. U., \& Suprajitno, S. (2020). Multimodal analysis on product placement in Korean drama: "Goblin", 8(2), $219-225$. https://doi.org/10.9744/katakita.8.2.219-225

[54] Ülker-demirel, E., \& Yıldız, E. (2020). The effects of audience's attitudes on actor, character, movie and product placement on the brand attitude. Istanbul Business Research, 49(2), 339-359. https://doi.org/10.26650/ibr.2020.49.0013

[55] Wulandari, K. A. (2019). The effectiveness of the Hyundai placement product on the Korean drama Descendants of the Sun against brand awareness surveys on the audience of the Korean dots drama in Tangareng. Journal of Communication Vission, 18(2). https://doi.org/10.22441/jvk.v18i2.9834 